\title{
9 \\ A Woman of the Kugika
}

Raggiana had married his first wife, Vine, when he had been warring in the north of the valley. He had brought her home as the widow of one of the vanquished, and with her was her small daughter, Cass, whom Raggiana learned to treat as his own. Cass was about nine years old when Original, son of both Raggiana and Vine, was born.

Raggiana acquired other wives including Spinach, who bore him three daughters, and Bluebell, the mother of his second son. Vine and Spinach joined forces to send away another wife he had obtained, and Spinach and Bluebell chased away yet another. When I knew Raggiana, he had four wives-Vine, Spinach, Bluebell (who died early in my stay), and Woman of Damba Clan. It was a long time before I realized that Woman of Damba Clan was married to him. I had learned that he had adopted her many years before. She was Original's age, and acted in every way as a kind of older sister to Raggiana's younger children by Spinach and Bluebell. But Raggiana had adopted her with the intention of making her the mother of his sons as soon as she was old enough. When her breasts began to develop, he took her quietly and without ceremony to sleep with him in a house where he sometimes entertained visitors from other clans. She did not go to courting ceremonies, as other girls of her age did, for her father-husband expected her to leap straight from childhood to womanhood. Her co-wives were already her 'mothers'; they did not resent her presence and try to drive her away. When she rebelled and Raggiana beat her with blazing wood from the fire, she ran to Vine and Spinach, assured of comfort and treatment for her wounds. 
Cass had attended courting ceremonies when she was Woman of Damba Clan's age. She belonged by birth to a clan that was not that of her stepfather, so it was understood that she could marry a Kugika man. She could not, of course, marry Raggiana himself, because her mother had already done so. Raggiana would have to give her to a man of a different subclan if he wished to profit from her marriage, for he could not demand marriage payments from a member of his own subclan. Cass's age-mates were all Kugika girls by birth, and she associated with men of all the friendly clans as they did, but, unlike her age-mates, she was able to have love affairs with 'brothers' who were not too closely related - that is to say, with youths of Kugika clan who belonged to the only other large subclan, Koimamkup. She attended courting ceremonies and led the untrammelled life of an unmarried girl for an unusually long period.

Kugika clan held its long-spaced Pig Ceremonial at this time. Raggiana shifted his various households to Kondambi, where they all lived for the first time as a family unit. But soon afterwards the Kugika warriors, fired by the spirit of unity and the hatred of traditional enemies the ceremonial used to evoke, marched on their old enemies the Kondika and engaged them in a series of battles, from which there was little respite for several years.

The Kondika were formidable opponents who had once driven the Kugika from their territory in a defeat which was so decisive that the Kugika had given extra women to the Ngeniga in exchange for some land at the Wozna River. They had managed to build up enough strength, while living there, to go back to their old territory and risk further clashes with the Kondika. They cautiously maintained their rights to the new territory by hunting there for wild game and by using some of the land for desultory gardening, in case they should need it again as a retreat from their traditional enemies.

Kondika warriors crept into Kugika territory one night and set fire to a house where nearly all the men of Penkup subclan were sleeping. Some of the Kugika took their sons, who were to succeed them as warriors, to stay at the Wozna River. They did this partly because it allowed them to raid the Kondika from several different directions, and partly because they felt it was safer. The most distinguished warriors among the Minj people were by some standards, the least courageous, and certainly Raggiana-who had a long record of victorious fighting and a reputation for innumerable killings both by spear and by sorcery-was one of the first to move. 
He took with him Vine and their little son, Original, and also Spinach-at that time a new wife by whom he hoped to have many sons. Bluebell had been with him for some years and seemed to be barren; her son was not to be born for several years yet. She was given the hazardous duty of taking loads of food to the Wozna River until Vine's gardens produced enough to serve the reduced household. Cass, too, was not worth protecting; Raggiana left her living at Kondambi with Bluebell and helping the older woman in her gardens.

The war with the Kondika ended with the Kugika returning in triumph to their own territory. They had often been defeated in the days when their clan had been strong and flourishing, but now they earned a unique reputation for having a strength in warfare that was unimpaired by their being greatly reduced in numbers. They resumed the ordinary business of life, tending their pigs and gardens without interruption, travelling far for trade, taking up the severed strands of the exchanges they had been conducting in pigs, women, and the plumes and shells they called 'pig-wealth'.

Kugika and Konumbuga clans were 'as brothers', because there had been much intermarriage which the members of both were eager to continue. Two of Big Insect's wives were Konumbuga women of Taukanim subclan, and Raggiana gave Cass to the Konumbuga Taukanim in exchange for one of them. The Taukanim gave yet another woman to the Kugikaagain, to Penkup subclan. But Cass's husband died before she had become reconciled to being married to him, and some of the Taukanim wives who had relatives among the Kondika resented her presence among them. She pleaded with her stepfather to take her back instead of leaving her to be appropriated by another Taukanim man. Bird, a young Kugika of Koimamkup subclan, offered a generous payment for her. Cass returned to the Kugika, and her stepfather's subclan gave the Konumbuga Taukanim another girl, Smoking, to take her place.

Cass's rebellion was not over when her first husband died, and she did not go willingly to Bird. Raggiana advised the young man to tie her up with a strong rope, of the kind that is used for tethering pigs, until she had learned to accept her new situation. He pointed out to Cass the advantages she had over other girls who had to leave home to live with their husbands at marriage. Her new husband was a Kugika man who 
belonged to the same community as Raggiana himself, and Original, so she would be able to see them constantly. Their presence would ensure that Bird could not ill-treat her.

Cass bore two children to Bird. One day she showed me, at one side of her unused cooking grove, an old house which had once been inhabited but was now beyond repair. The grass thatching was grey and matted, and tall weeds had grown up through the roof.

'My children,' Cass told me. 'We put them in there.'

We trampled down the undergrowth to approach the doorway. It was fastened with cross-bars which had the driftwood appearance of wood that is long exposed to the weather. A small snake rustled in the undergrowth. Cass tore away some of the cobwebs and removed the cross-bars. We could see, just inside, the dim shapes of two bundles wrapped in mouldy bark cloth and lap-lap material, lying side by side.

'They just fell sick and died,' Cass told me flatly. Then she began to relate with a sudden surge of anger, something Bird had done. I had witnessed many quarrels between them. Trouble between Bird and Cass was not simply a domestic concern of a man and his wife, but a substantial threat to the traditional friendly relations between the two largest subclans of Kugika clan. Their quarrels were nearly everyone's concern, and their brawling was a signal for people to drop what they were doing to watch for the outcome. They had publicly voiced many grievances against each other, but these were often incidental to their deepest resentments.

I knew of the custom of depositing valuables with the dead. A person was ordinarily buried in a shallow grave, but an important man was laid inside a little house or mausoleum where his relatives might visit and watch him decay. They would decorate the body as for a great dance, with the richest plumes arranged about his head, goldlip shell at his throat, and green snailshell at his waist. These ornaments were removed from a man of no importance when he was lowered into the grave. But if the dead man were someone of renown, the decorations were offered with other valuables as a tribute to his greatness and a guarantee that the relatives who provided them had not hoped to benefit from his death. I had seen tubes of costly powdered paint emptied over a corpse, and valuable shells smashed into fragments to be strewn over it in an extravagant gesture. 
Parents might demonstrate their grief at the loss of a well-loved child by treating the body in some respects as if it were that of a person of eminence. The dead child had this importance only for two people, the mother and the father. Parties of men visited the charnel house of a great man to see for themselves that the flesh had fallen away from the bones, then together gathered the bones and together disposed of the valuables. There were no clear rules a mother and father could follow if they decided to treat a dead child as a person of importance. The usual solution was to bury the child in an ordinary grave and, if they wanted to demonstrate that he had been especially important to them, they might build a little house on top of the grave. But Cass and Bird wanted to keep their children with them, even in death. They placed the bodies in Bird's house and fastened the entrance. Evidently neither parent felt any real obligation to watch the progress of decay and decide the fate of the children's bones. Each went to the house occasionally, removed the cross-bars blocking the doorway, looked upon the two bundles, and thought about the children.

On one such visit, Cass told me, she discovered that Bird had removed the valuables they had deposited there. The horror she expressed, crouching beside the torn cobwebs, made Bird's action sound like an unnatural crime, an act of violence against her babies. This was a different kind of grievance from the complaints I had heard so far. 'Look at my sweet potatoes! The pigs have been digging up the vines and making great craters in my garden, and Bird does nothing about it ... This is my house. As you can see, it needs repairing!'

Bird had another wife, who had also borne him two children. Like the two who had died, they were a boy and a girl. Their mother had called the little girl Cass after her co-wife. But Cass had always resented Bird taking a second wife and, to prevent her from making it intolerable for the other woman to remain, Bird had built the two women's houses a mile away from each other. This woman told me her real name, but everyone knew her as 'Ugly Mouth'. The nickname referred to a grotesque facial disfigurement she had received a long time before in a fire. An unsightly scar drew her lips toward one eye in a lop-sided grimace. Cass was an attractive woman by Minj standards, and she resented being neglected in favour of a creature who was plainly hideous. She was jealous of Ugly Mouth, too, when her own children died and Bird could still stroll about holding his young son or little Cass by the hand. 
Cass appealed to Raggiana and Original to help her when she quarrelled with her husband, but they remembered the valuables he had given them for themselves and the Taukanim, and were anxious to placate him. Bird had given them a further payment when Cass's children were born. They returned most of it later when the children died. But they had presented the couple at various times with pigs to rear, and they were expecting Bird to give them some of the offspring of these animals. Their account with him could not be settled in any simple fashion if they were to take Cass back and give her to another man.

Bird struck Cass for picking up a bundle of pandanus fruit he had put on the ground. She complained to her stepfather that Bird was ill-treating her, and showed her bloodied head and shoulders as proof. Raggiana refused to upbraid Bird, so she thought of asking her brother, Stone Herb, who lived on the other side of the Wahgi River, to come and help her.

Cass had already visited Stone Herb, at Raggiana's suggestion, taking a present of food as a gesture of friendship. This was Raggiana's implicit reminder to Stone Herb's clansmen that the Kugika would give them pork after the pig-killing in exchange for the loan of some ornaments to wear in the dances. As a further gesture of friendship, Cass had woven a net apron for Stone Herb and had sent a message that she would bring it to him on a further visit. Stone Herb had sent word for her to come on a certain day, and she had visited him without consulting her husband. Bird had beaten her when she returned, and then had said, 'You can't go over there again. If you go to see your brothers, they will give you to another man, but you are married to me and I won't stand for it.' Stone Herb received a message that Bird had threatened to kill him, and he came to Kondambi prepared to defend his sister against a husband who had beaten her without cause. A crowd gathered, as usual, on the ceremonial ground to hear and take part in the discussion.

'I just have to talk,' Bird complained, 'and Cass is tearful and angry ... You're not a young girl who attends courting ceremonies-I married you! But if I say anything, you cry.'

'I married you, yes,' Cass agreed. 'Well, I'll marry another man.'

'The day after tomorrow,' Big Insect said, 'we'll give Bird a collection of valuables, and Cass can come back to us.' 
This was Big Insect's tactful way of reminding the people of Penkup subclan that if Cass were to leave Bird and marry another man the payment he had given them would have to be reimbursed. At a time when they needed all their plumes and shells to wear in the dance.

Stone Herb asserted that the marriage was not valid, because he and Cass's other true paternal relatives had not received any payment from Bird. Big Insect ruled that Raggiana had a perfect right to the marriage payments, because Vine had put the baby Cass in her string bag and gone to Raggiana, who had brought up the girl as his own child. Stone Herb objected that Raggiana had married Vine by capturing her in an old fight, and he threatened that if Bird and Cass were to quarrel again he himself would take the case to the Court of Native Affairs. Big Insect, as luluai, ended the discussion as he had ended many others, by saying, 'It is better for Cass to stay married to Bird. That is the end of the matter.' But Bird grinned broadly and could not help commenting, 'If Cass actually goes to another man, we'll talk further.'

A month passed. One day, Cass had gone to the Government Station to sell some vegetables to the wife of a resident officer. She used to sell them for small quantities of coloured beads, which she hoarded to string together and hang about her neck and arms. Bird was talking to some other men in a public place when she rushed up to him and blurted out her story. She had been walking along the road, she told him, when a native who worked as a household servant at Minj had followed her and asked where she was going. 'I am going home,' she had answered. 'You're going to your lover, not to your house,' he had laughed, and dragged her into the bushes. A native policeman had come along the road, and they had sprung apart and fled their separate ways. Cass had come straight to Bird to tell him about it.

Bird discussed the incident with the other Koimamkup men, and concluded angrily that Cass had only told him about it because she had feared that he might hear of it from the policeman. He snatched her lap-lap cloak and the scarf she wore on her head, and tore at her string apron. He tried to pull off the beads she was wearing, but Cass protected them. Bird shouted that it was plain that she had a lover because she decorated herself with scarf and beads and lap-lap whenever she visited Minj. He did not mind his wife having a lover; what had offended him was that Cass had drawn public attention to her adulteries. Since everyone knew about the incident, he granted Cass's plea that it should be reported 
to the Court of Native Affairs. He and Cass told me later that the officer hearing the case had asked Bird whether he would prefer the offending native servant to be sent to jail or to be ordered to pay Bird two Australian pounds as a compensation for usurping his marital rights. Bird chose the money. He was convinced now that Cass's attempts to break up their marriage did not express a simple wish to sever relations with himself, but a desire to seek with some other man a variety of sexual experiences. Original said disgustedly, in conversation with me, that Cass was nothing but a 'wandering woman', a harlot.

Some months passed, and Cass's reputation for being an adulterous woman who enjoyed public arguments was more and more firmly established. During this time, she did in fact commit adultery on one occasion with a native policeman. The case was dealt with by the Court of Native Affairs, and Cass had to serve two months in jail. She worked with other prisoners on the Government Station, and had countless opportunities to meet and talk with the Kugika when they visited the Station. Original often went to see her. He told me that she was sad at the thought that she might still be in jail when the Kugika killed their pigs at the end of the ceremonial. In his view, she deserved to miss the pig-killing; Bird had given a large payment for her, so she should have been a good wife. Bird himself frequently predicted that Cass would desert him for another man as soon as she was free. His clansmen muttered that even the Government knew now that Cass was a harlot.

Her mother, Vine, was an old woman and did not visit Minj as the others did. Original and I found her one day going through the contents of a string bag Cass had left in her care. It contained all of her daughter's possessions. There were two similar net bags folded inside it; a blanket, a red lap-lap, a cake of soap, and a steel spoon; a parcel of beads which were strung together, and odd little parcels of beads still unstrung; four green snailshells strung on a greasy cord for wearing around her head; a rope of small cowrie shells and a glass jar containing tambu shells, which are smaller shells resembling cowries; a spare apron, and a bundle of home-made cord; a parcel of European salt. Vine opened each of the little parcels wrapped in newspaper and coarse bark-cloth, and examined its contents closely. She tasted the salt, and tried the green snailshells on her head. She told us she was sorry for Cass, who had been so long in jail. Then she asked Original to tell the European officer to let her daughter 
come back to Kondambi and look after my house and garden instead of doing similar work on the Government Station. I had to discourage the idea.

Eventually Cass came home, and she insisted on staying with Vine and Original. Raggiana told her that she must go back to her husband, and he cunningly encouraged Bird to take her back by force. The quarrels between Bird and Cass became more violent and more frequent. They culminated in a great public dispute when Raggiana and others demanded to know what grounds Cass had for thinking she was justified in leaving Bird. The examination grew fiercer as Cass recited all of Bird's trifling neglects-so fierce that I was expecting her to be goaded into mentioning the valuables her husband had taken from the bodies of their children. But finally, angered, humiliated, and obviously ashamed, Cass cried out to the assembled company, 'Bird did something evil. He tried to make me eat his penis.'

Cass referred to the crude insult which, spoken at the height of a serious private quarrel, may drive a man's wife to hang herself. The reciprocal insult, uttered by a woman, may lead her husband to beat her insensible. But if I understood Cass correctly, Bird had insulted her physically as well as verbally. I asked my interpreter from the other side of the valley, who was listening with me, to tell me exactly what Cass had said. He was a Mission boy, whose ideas of propriety were commendable but inconvenient. He gazed steadfastly at the ground and curled the splayed toes of one foot against the great toe of the other in embarrassed silence.

Konangil-Original's closest age-mate, and (like Original himself) an unfailing source of information-came over to us. He told me simply that Bird had uttered the forbidden words and then, hurling his wife roughly to the ground, had tried to force her to comply with the insulting demand. Konangil echoed Cass's judgment that Bird had done something bad, and added that he himself had never heard of the practice before. Bird, he explained, had a friend who was a policeman from the coast; perhaps he had learned it from him.

Bird was plainly astonished by his wife's revelation. The men of Penkup subclan, who had been supporting him earlier in the dispute, suddenly agreed with a suggestion from Big Insect that they should take the case to the Court of Native Affairs and let the administrative officer decide whether or not the marriage should be dissolved. 
The Court decided that Cass should leave Bird and live with Raggiana and Original, and that they should settle amicably between themselves the ownership of the pigs Cass had tended. It ruled quite clearly that her stepfather and half-brother must not contemplate giving her to another man. Ugly Mouth had been looking after all the pigs Bird himself had owned. Some had died, and Raggiana and Big Insect had given him others for Cass to care for so that he would have plenty to kill at the end of the Pig Ceremonial. Raggiana seized these pigs as soon as Cass's marriage was dissolved, but Bird sought the advice of his friend the policeman and sued for them successfully in court. The Court's decision that Bird should keep the pigs required that he should make no further claim on Penkup subclan for the valuables he had given in marriage payments. Raggiana had had no intention of surrendering the valuables, and when he found that he had no chance of regaining the pigs, he decided that Cass must go back to Bird, despite the decision of the Court. He and Original took Cass's bag of belongings back to the house she had occupied as a wife of Bird.

Raggiana and Big Insect-blood brothers, one the traditional leader and the other the Government-appointed headman-had lately had many differences. Raggiana had been urging that the pig-killing should be hurried on before the clan's existing stock was further depleted through illness, whereas Big Insect had been trying to meet the Government's increasing demands for labour as the programme of road-building was intensified. Now Big Insect insisted that Cass was no longer Bird's wife because the Court at Minj had officially dissolved the marriage. He recovered Cass's belongings and deposited them with the widow Guardian, whose son was his staunch supporter. Bird interpreted this action as evidence that Big Insect wanted to give Cass to another man.

Cass was concerned about one of her pigs. She had once earned a great quantity of beads by doing some work on the Government Station, and had given them to a relative in exchange for two piglets. One she had cooked and shared with her husband; the other she had continued to tend. She still had a few of the beads left, and she showed them to the Government interpreter, Arrow.

'The administrative officer knows all about your case,' Arrow advised her. 'Keep the rest of the beads. If Bird doesn't give you the pig, tell the Court how you obtained it, and show the beads as proof.' 
Bird kept the pig with the others and continued his efforts to make Cass go back to him. She was staying with Guardian, but spent much of her time with Vine and Original. One day she went off with the other women of the Kugika to carry firewood to Minj. The women drifted back at their leisure. Cass stayed behind to have further words with the interpreter Arrow about Bird's refusal to give her the pig she had claimed. Then she set off for Kondambi with two Konumbuga men who wanted to visit their Kugika relatives on their way home.

Bird hid in a tangle of wild sugarcane at the shallow river crossing, waiting for her. He seized her and tried to throw her into the river, but she struggled to free herself and the other men held him off until she escaped. He chased her, dragged her to the house she had lived in as his wife, and ordered her to cook him some food. Cass refused, and fled to Kondambi as soon as she managed to get away from him. Bird pursued and tried to drag her back, striking her savagely and shouting at her. He stopped when he realized that a crowd had gathered to watch them.

It was getting late. A mist of rain had gathered between the mountains up the river and would soon be coming to Kondambi. Guardian took the steamed spinach and asparagus out of her earth oven and walked towards her house. Bird called out, asking her to take Cass's belongings down to his house. But Guardian pretended not to hear him and continued preparing her meal. The rain swept down, and the people dispersed. Bird went to the men's house he shared with other members of his subdivision of Koimamkup subclan . Cass slept with one of Guardian's daughters-in-law. The next day a Kugika woman asked me whether I had any news of Cass that morning. She wanted to know whether Cass had escaped, or whether Bird had succeeded in killing her.

Months passed, and the Kugika were nearly ready, after countless delays, to hold the final ceremonies and kill their pigs. More and more friends and relatives were staying at Kondambi to view the dances, and the women had to go to more distant gardens to find enough vegetables to feed them. Cass had gone back to live with Vine and Original, and was busy helping Raggiana's womenfolk to feed his guests. One day she took Spinach's young daughter to gather asparagus near the Wahgi River. They returned to find three of the Koimamkup women angry with them for taking asparagus from Koimamkup gardens. 
Big Insect said that Cass must give the Koimamkup women some beads to compensate them for the theft of asparagus. Raggiana disagreed; the Koimamkup women, he said, had already taken banana leaves from Penkup gardens. A crowd had gathered, and a Koimamkup man who was leader of Bird's subdivision said that if Penkup and Koimamkup stole from each other they must pay indemnities.

Cass protested that she had not stolen the asparagus, because the Koimamkup had given her the gardens. One of Bird's age-mates said that if this were so Cass should cook the asparagus and give it to her husband to eat. She must not stay any longer with her mother and stepfather.

There was a lot of muddled discussion about the extent to which women of the two subclans had been helping themselves to the produce of each other's gardens. Then suddenly Bird seized Cass and dragged her towards one of the Koimamkup houses. A man and three women helped himtwo of the women whose gardens Cass had robbed, the husband of the third, and this man's brother's wife. Big Insect, as luluai, ordered the women to desist.

'Get a rope and tie her up!' Bird cried to the Koimamkup people. 'Throw her into my house so that I can copulate with her and show her she is married to me.'

Most of the people had built fences around their houses in the temporary village to discourage pigs, dogs, and human thieves. Bird, dragged Cass inside the enclosure he had made around his houses. Cass struggled. The Penkup would not help her, because they did not want to come to blows with the Koimamkup, their 'brothers'-at least until they had all killed their pigs. Cass was trapped inside the enclosure, with three of Bird's age-mates guarding the entrance and onlookers swarming around the fence.

'Are you a girl who attends courting ceremonies?' Bird demanded of Cass.

'She's a woman afflicted with mushroom madness,' one of his age-mates mocked.

'The luluai says not,' Cass stated bravely. 
Although Big Insect wanted to see that the Court order for Cass to stay with her stepfather was obeyed, he did not intervene when he saw that the Koimamkup were unanimously insistent on keeping her. Cass stayed as a prisoner in Bird's house, but managed to escape during the night.

The next morning Spinach offered the Koimamkup women some beads as compensation for the asparagus Cass and her own little daughter had stolen. They rejected them as being inadequate. But the husband of one of these women (Love, Chapter 6) had just taken a new bride, and they were preoccupied with the older wife's efforts to drive her away. The theft was temporarily forgotten, to be remembered about a week later when Bird made a further attempt to take Cass back by force. Big Insect referred the case to the Court of Native Affairs and Cass went to jail for a short term, this time for stealing.

Cass went across the Wahgi River to Banz as soon as she was released. A policeman named Eating, whom she and Original had known at Minj, was now stationed there, and he had invited them to visit him whenever they wished to get some produce from his garden. Cass went to get some. Banz was only a few hours' walk away, and normally she would have returned the same day or the next, but four days passed and Original began to worry. He told me that he did not know whether Cass had decided to stay with Eating as his wife, whether she had gone to another man, or whether she had drowned in the Wahgi River. He thought it unlikely that she would have drowned by accident, but wondered whether Bird had followed her and pushed her into the strongly flowing stream. If she did not come back tomorrow, Original said, he would go and look for her body in the river. But he did not go; he thought he would wait a little longer. Then Cass came back, carrying a great load of vegetables she herself had dug from Eating's garden, and bearing presents from her brother, Stone Herb, whom she had visited on the way.

The men of Penkup subclan, led by Raggiana, were in further strife with the Koimamkup, whose pigs had been ravaging their gardens. Raggiana threatened them, 'If you don't give us compensation for the damage your pigs have done, and tie up the animals so that they can't do more, you will regret it. When Cass goes to another man, I shall play no part in adjusting the marriage payments. You yourselves can go and persuade the new husband to pay you.' 
Cass chose the time when Raggiana had a grudge against the Koimamkup to go to the Government Station and complain that Bird had not yet returned to her the pig she had bought with her hard-earned beads. A policeman arrived with orders to escort Bird and the pig to the Court of Native Affairs. Bird was reluctant to go, and he kept the policeman waiting for half an hour while he went to fetch the pig. Then he came back and said that he could not find the animal: Ugly Mouth was in hospital at Minj, and he did not know where his pigs were. Cass interrupted to say that Ugly Mouth was not in hospital but had been seen visiting her brothers on the other side of Minj two days before.

The native policeman grew impatient. Raggiana had told him that he would accompany him to Minj in order to complain about the pigs that had been destroying his gardens. The policeman turned to the crowd now gathered on the ceremonial ground, and demanded that all the Kugika women should round up all their pigs and lead them to Minj. Once there, he said, they could sort out Cass's pigs and the animals that had been breaking into Penkup gardens.

The Koimamkup had been murmuring resentfully among themselves. Now three of them spoke out loudly, each reiterating what the other two had said - that Cass's marriage payments had never been adjusted, and that this question should be settled before a decision could be made about one particular pig. The luluai Big Insect, made bold by the presence of the policeman, commanded the Koimamkup to find the pigs immediately.

The Koimamkup drifted away, but the Penkup remained on the ceremonial ground to discuss Smoking, the girl they had given to the Konumbuga Taukanim several years ago as a substitute for Cass. She had come back to them with various complaints, and they were trying to decide whether to take her back to her husband or give her to another man. It was a lively issue, likely to involve them in several hours' discussion for several successive days. The policeman had arrived with Cass at about eight o'clock in the morning; at eleven, he was still at Kondambi and the pig had not yet been found. Bird had gone off saying that he did not know where the pig Cass wanted was likely to be, and the policeman had pushed another Koimamkup man in the direction Bird had taken. It was three o'clock when Bird appeared with the pigs Cass had formerly tended and the policeman was able to depart for Minj. The Court decreed that Cass should have the pig she herself had bought, and that Bird should keep the others. 
Raggiana was planning the programme of the final ceremonies before the pig-killing and holding public meetings to make sure that everyone concurred. The women were busier than ever, bringing more loads of green vegetables from the Wozna and the Wahgi. Some had already brought their pigs to Kondambi, ready for the slaughter.

I scarcely saw Cass during this period. Once, when I encountered her briefly, she told me with relish: 'As soon as the pigs are killed, Ugly Mouth is going back to the man she was married to before, because Bird is always hitting her without cause. Not even an ugly woman no man will look at wants to stay with Bird.'

I did not know whether Ugly Mouth would in fact go back to her first husband. Whether she did or not, Bird would undoubtedly renew his efforts to take Cass back. Cass's divorce was still not final when I left Kondambi. The matter of marriage payments had never been satisfactorily adjusted, and inevitably the question of her remarrying would sooner or later arise.

Cass's life would have been different in many details if the Australians had not come to the Wahgi Valley and established control there during her lifetime. Her separation from Bird would have been even more tenuous an arrangement than it was if she had not had the support of the Court of Native Affairs and of her family's friends among the interpreters and native police.

Cass never referred publicly to Bird removing the valuables from the bodies of their children-because, she told me, he might be put in jail if this were known, and the clan needed all its men to demonstrate its strength in the dances of the Pig Ceremonial. Cass never identified herself with the subclan of her husband, but she was Kugika by informal adoption and long association, since her mother had married Raggiana.

When the Court of Native Affairs dissolved the marriage of Cass and Bird in 1955, the Acting District Officer commented that 'the litigation has been over a period and the story appears to alter on each occasion'. Three years later the court heard a claim by an ex-constable named Dure of Chimbu for the custody of a child of his, Cooking, a two-year-old boy who was living with his mother, Cass. Raggiana testified that Dure did not go to see the child when he was born and had not previously shown any 
interest in him. The patrol officer who heard the case ruled that because Dure had made no payment for Cass he had never married her 'by local custom' and therefore had no claim on the child of their union.

In 1963-64 Cass's brother, Original, who had one daughter but no sons, was acting as father to Cooking. He was confident that the real father would never come back and get the boy, and he was determined that the lad would grow up as a Kugika. Other Penkup people told me that as Cooking did not know his father he would think of Original as his own parent. Being a Kugika, he would not be able to marry Kugika girls, for he would regard them as sisters. Original explained that this arrangement was possible because Cass herself was Kugika by adoption, not by birth. If strangers were to tell Cooking later that his father was a Chimbu man, he would not believe them. 'But my father is here,' he would say, referring to Original. Original would have named his real son, if he had had one, Raggiana, to perpetuate the name of the lad's grandfather; similarly, when Cooking grew up and married he would call his son Original after the man he knew as 'father'.

Cass heard that I was intending to drive to Goroka, and she pleaded with me to take her as far as Chimbu so that she could see Dure and go back to being his wife. I consulted Original, who forbade me to take her along.

'Cooking has to stay here,' he said. 'The Chimbu man doesn't want Cass. When he left Minj to go back to Chimbu, Cass wanted to go with him but he said he already had a wife and children at home and didn't want any more. If you were to take her to Chimbu and leave her there, Cooking's father would give Cass to someone else. She and Cooking would be too far away for us to watch their interests. The Chimbu has never looked upon me as a brother-in-law, and it is better that Cass doesn't see him.'

I did not take Cass to Chimbu, though she asked me to do so on other occasions as well.

Bird had acquired another wife, Goldlip, and had built a 'women's house' for her at Gwaip, the Burikup place, though he himself was Koimamkup. He told me he had built it there because Ugly Mouth, who was still with him, had caused quarrels between him and Cass when they had lived as co-wives in the same locality. Bird's version of how his marriage to Cass was dissolved was that she had been adulterous and he himself had sent her away. She had wanted to come back to him, he said, but he had been adamant. He did not want a wandering woman for a wife. 
This text is taken from Wives and Wanderers in a New Guinea Highlands Society: Women's lives in the Wahgi Valley, by Marie Olive Reay, published 2022 by ANU Press, The Australian National University,

Canberra, Australia.

doi.org/10.22459/WWNGHS.2022.09 